\title{
Historicidade do reinado de Deus
}

\author{
Historicity of God's Reign
}

FRANCISCO DE AQUINO JÚNIOR (DDa

\section{Resumo}

Uma das características mais importantes da teologia do século XX foi a redescoberta da historicidade ou da dimensão histórica da salvação ou reinado de Deus, centro da vida e missão de Jesus e de sua Igreja. Isso marcará de modo decisivo o Concílio Vaticano II, desencadeando um processo de renovação teológico-pastoral que terá na Igreja da América Latina a partir da Conferência de Medellín, com sua evangelização libertadora e sua teologia da libertação, sua expressão mais fecunda e profunda. Essa é a problemática central deste artigo. Depois de algumas considerações históricas sobre essa problemática, trataremos da dimensão histórica do reinado de Deus e indicaremos seu critério fundamental de realização e verificação.

Palavras-chave: Salvação. Reinado de Deus. Historicidade. Libertação. Pobres.

\section{Abstract}

One of the most important characteristics of twentieth-century theology was the rediscovery of the historicity or historical dimension of God's salvation or God's reign, the center of the life and mission of Jesus and his Church. This will decisively mark the Second Vatican Council, unleashing a process of theological-pastoral renewal that will experience in the Church of Latin America, starting with the Medellin Conference, with its liberating evangelization and its theology of liberation, its most fruitful and profound expression. This is the central problem addressed in this article. After some historical considerations on this issue, we will discuss the historical dimension of God's reign and indicate its fundamental criterion for realization and verification.

Keywords: Salvation. God's reign. Historicity. Liberation. Poor.

a Faculdade Católica de Fortaleza (FCF), Fortaleza, CE, Brasil; Universidade Católica de Pernambuco (UNICAP), Recife, PE, Brasil. Doutor em Teologia, e-mail: axejun@yahoo.com.br 


\section{Introdução}

Reinado de Deus ${ }^{1}$ é uma das muitas imagens/expressões usadas na Escritura para falar da ação de Deus no mundo. Trata-se de uma imagem/expressão proveniente do âmbito político (rei) que indica ação de governo ou exercício de soberania real (reinar). Deus é rei e sua ação consiste em reinar. Mas para compreender adequadamente o reinado de Deus, isto é, que tipo de rei é Deus e qual a sua forma de reinar, é preciso observar sua ação na história de Israel e, na plenitude dos tempos, em Jesus de Nazaré. Ele faz do anúncio da proximidade do reinado de Deus o centro de sua vida e missão (Cf. Mc 1,15; Mt 4,23; Lc 4,18s.43), indicando com sinais e com parábolas sua proximidade e chamando à conversão. Os evangelhos dão testemunho da ação salvífica de Deus em Jesus ou de como através de Jesus Deus vai exercendo seu senhorio na vida daqueles que o acolhem na fé e se deixam conduzir por seu Espírito, constituindo-se, assim, como o novo povo de Deus: o povo sobre o qual Deus reina, o povo que vive de acordo com a vontade de Deus². Assim nasce o "movimento de Jesus" e, a partir dele, as primeiras comunidades cristãs (Cf. VELASCO, 1996, p. 13-93).

O curioso é que isso que significava uma transformação radical na vida dos cristãos e de suas comunidades e, a partir deles, a modo de fermento/sal/luz, do conjunto da sociedade, foi sendo instrumentalizado ideologicamente para legitimar impérios ditos cristãos e/ou perdendo relevância histórica através de sua protelação para o fim dos tempos ou de sua espiritualização e redução ao âmbito privado. Só a partir do final do século XIX a teologia vai, aos poucos, não sem ambiguidades e conflitos, recuperando a historicidade da salvação ou do reinado de Deus e, assim, a densidade teológica dos acontecimentos históricos.

\footnotetext{
${ }^{1}$ Embora a expressão grega basileia to Theou seja comumente traduzida por "reino de Deus", na medida em que ela indica o agir soberano de Deus ou o exercício de seu poder régio na história, seu sentido é mais bem expresso em termos de "reinado de Deus". Mais que um espaço territorial (reino), basileia designa ação régia/soberana (reinado) (Cf. SCHNACKENBURG, 1974, p. 323-325; JEREMIAS, 2008, p. 162; FABRIS, 1988, p. 106; LÉON-DUFOUR, 2003, p. 26s).

2 É neste sentido que falamos de "historicidade do reinado de Deus": um dinamismo que se realiza na história (salvação na história), que se realiza de modo histórico, isto é, mediante a apropriação desse dinamismo como possibilidade de fazer a vida de acordo com a vontade de Deus revelada em Jesus Cristo (salvação histórica) e que faz/tem história (história da salvação) (Cf. ELLACURÍA, 2000, p. 597-628; AQUINO JÚNIOR, 2010, p. 107-113, 161-169).
} 
Nossa reflexão, aqui, insere-se nesse contexto de redescoberta da historicidade da salvação ou do reinado de Deus que atinge seu ponto alto no Concílio Vaticano II e em sua recepção na Igreja Latino-americana. Depois de algumas considerações históricas desse processo, trataremos da dimensão histórica do reinado de Deus e indicaremos seu critério fundamental de realização e verificação.

\section{Considerações históricas da problemática}

Não vamos retomar aqui os estudos bíblicos sobre o reinado de Deus no Antigo e no Novo Testamento (Cf. SCHNACKENBURG, 1974; JEREMIAS, 2008, p. 133-193; LÉON-DUFOUR, 2003, p. 23-118; BARBAGLIO, 2011, p. 261-307; SOBRINO, 1996, p. 105-159). O que nos interessa neste momento é chamar atenção para sua instrumentalização ideológica e/ou espiritualização ao longo dos séculos, bem como para a recuperação de sua densidade e relevância históricas no século XX.

É curioso como aquilo que na Escritura indica reconhecimento/confissão de e/ou confiança/esperança na ação salvífica de Deus na vida de seu povo foi sendo associado a impérios e poderes opressores ou sendo espiritualizado a ponto de perder sua densidade e relevância histórico-salvíficas. Trata-se de um processo longo e complexo que não deve ser simplificado nem em suas causas nem em suas expressões e que não deixa de ter raízes bíblicas... Dentre os muitos aspectos que explicam e ajudam a compreender esse processo, dois são particularmente relevantes e determinantes, por mais paradoxal que pareça: "helenização" da fé e "constantinização" da Igreja.

Por um lado, a inserção e o crescimento da Igreja no mundo helenístico só podiam levar a um processo de inculturação da Igreja nesse mundo e, portanto, de "helenização" da fé. Isso é constitutivo do dinamismo da fé que só pode ser vivida em uma determinada cultura e foi condição de possibilidade para o enraizamento e a propagação da Igreja nesse mundo. E não há razão aqui para oposição e negação radicais do processo de helenização da fé. Pelo contrário. No entanto, é preciso reconhecer que a cultura greco-helenista é marcada por um modo de pensar pouco afeito ou mesmo um tanto avesso à historicidade e isso teve graves consequências tanto para a compreensão de 
Deus e de seu desígnio salvífico quanto para a vivência e intelecção da fé. Acabou favorecendo/levando a uma espiritualização e des-historização da salvação ou do reinado de Deus, postergado ou mesmo relegado para o fim dos tempos e desprovido de relevância histórica. Durante séculos, diz Ellacuría, a filosofia helenista, platônica e aristotélica, constituiu "o marco teórico" de interpretação da "realidade" como um todo, também "das relações de Deus com o homem e do homem com Deus". Trata-se de uma forma de pensar centrada na essência permanente e imutável das coisas, na qual "a história carecia de realidade e razoabilidade científica". Isso levou a uma deshistoricização da salvação "com consequências graves tanto para a práxis histórica como para a interpretação e eficácia da fé cristã". Infelizmente, parece que o "molde filosófico do pensamento grego" foi mais determinante que a "matéria moldada nele". De modo que, "na passagem do que era uma experiência fundamentalmente biográfica e histórica, com sua própria interpretação, para uma formulação metafísica, a historicidade tinha ficado diluída em benefício de uma essencialidade estática”. Nessa forma de pensar, na melhor das hipóteses, podia-se admitir que "a salvação tinha se dado (acidentalmente) na história, mas não era (essencialmente) histórica" (ELLACURÍA, 2000, p. 597s). E, assim, a problemática do reinado de Deus, centro da vida e da missão cristã, vai se tornando cada vez mais uma problemática pós-morte, relativa ao fim dos tempos, com pouca relevância e incidência histórica...

Por outro lado, a "aliança" da Igreja com os impérios, mais que fermentar esses impérios com a novidade do Evangelho, tornando-os "sinal e instrumento" do reinado de Deus nesse mundo, levou a um processo de instrumentalização ideológica da Igreja por esses impérios, bem como a um processo de acomodação da Igreja aos interesses, à lógica e à estética imperiais. De perseguida pelos poderes desse mundo, a Igreja vai se tornando uma aliada estratégica e fundamental desses poderes. Seus ministros vão se habituando à vida palaciana. A estética palaciana vai se impondo sobre a estética de Belém, da ceia e da cruz (veja os templos, os ministros, as vestes e as solenidades litúrgicas...). O anúncio profético do reinado de Deus que é Boa Notícia para os pobres, marginalizados e sofredores vai perdendo espaço para a defesa "religiosa" do status quo da sociedade (Cf. PETERSON, 1999, p. 61-95). É verdade 
que a profecia nunca desapareceu completamente da vida da Igreja (Cf. COMBLIN, 2008). Mas é verdade também que se produziu ao longo dos séculos um distanciamento da Igreja do dinamismo salvífico inaugurado por Jesus, com a consequente mudança de lugar social da Igreja das periferias para os palácios. Esse processo tem sido muitas vezes designado ou indicado em termos de “constantinização" da Igreja (GONZÁLEZ, 2003, p. 308-321). Por mais que não se possa responsabilizar Constantino por todo esse processo, que se possam identificar indícios ou tendências desse processo anteriores ao século IV e que ele tenha adquirido características novas e diversas ao longo dos séculos, não se pode negar que com Constantino se dá uma virada na Igreja e que ele representa um marco na história do cristianismo. Por isso, não é falso nem de um todo inapropriado nomear esse processo em termos de "constantinização" da Igreja. Essa expressão "serve para designar esquematicamente as profundas transformações que acontecem em virtude da conversão da fé cristã em religião oficial de toda uma sociedade" e que "marcaram o rosto do cristianismo até o nosso tempo" (GONZÁLEZ, 2003, p. 308), fazendo com que "o reinado de Deus [deixasse] de ser uma experiência real dos cristãos na história para se converter numa categoria escatológica [...] experimentável depois da morte, mas não na história" (GONZÁLEZ, 2003, p. 310).

Só ao final do século XIX, com o surgimento da teologia liberal e as controvérsias por ela desencadeadas, essa situação começa a mudar e, aos poucos, a teologia vai recuperando a centralidade do reinado de Deus na Igreja e sua densidade e relevância históricas, provocando assim uma verdadeira reviravolta na escatologia cristã (Cf. GIMÉNEZ, 2018, p. 53-86). O interesse pelo chamado "Jesus histórico", por mais problemático que seja, sobretudo por seu reducionismo positivista e por sua contraposição ao chamado "Cristo da fé", provocou uma volta a Jesus. Como reação a esse reducionismo historicista da teologia liberal, surge a chamada "escola da escatologia consequente", recuperando o caráter escatológico da mensagem de Jesus e afirmando que "Jesus é fundamental e exclusivamente um profeta escatológico". Bultmann, por sua vez, com seu projeto de "desmitologização do Novo Testamento", não obstante seu reducionismo fideísta e existencialista, reagindo contra o reducionismo da chamada "escatologia consequente", enfrenta-se com a problemática da relevância de Jesus e de sua mensagem para nossa vida "aqui 
e agora". Reafirmando com Bultmann a relevância da salvação para o homem de hoje, mas superando seu reducionismo existencialista, Culmann recupera a centralidade da "história da salvação" na Escritura, mostrando como no centro da mensagem de Novo Testamento está a ação de Deus na história, fazendo dela uma "história de salvação". Todo esse processo tenso e complexo de renovação da teologia deságua no Concílio Vaticano II com sua compreensão da Igreja como "povo de Deus" (Cf. LG, 9-17) - "sacramento" ou "sinal e instrumento" de salvação ou do reinado de Deus no mundo (Cf. LG, 1, 9, 48; GS 42, 45; AG, 1, 5) e sua incipiente teologia dos "sinais dos tempos" (Cf. GS, 4, 11, 45; UR, 4) e em sua recepção/tradução latino-americana a partir da Conferência de Medellín e da teologia da libertação em termos de libertação e/ou "opção pelos pobres".

Fato é que, a partir do Concílio Vaticano II, sobretudo de sua recepção/atualização latino-americana, não obstante ambiguidades e conflitos, a historicidade da salvação ou do reinado de Deus passa a ocupar o centro dos interesses e dos debates teológicos, bem como o núcleo das controvérsias teológicas.

\section{Dimensão histórica do reinado de Deus}

Não obstante sua concepção ilustrada da história (Cf. GONZÁLEZ, 1989, p. 342; 1992, p. 61), Oscar Culmann é uma referência fundamental no processo de recuperação da historicidade da salvação ou do reinado de Deus na teologia contemporânea. No contexto das controvérsias escatológicas entre a chamada "escatologia consequente" que afirmava que o Reino de Deus seria uma "realidade futura" (Loisy, Schweitzer) e a chamada "escatologia realizada" que afirmava que o Reino de Deus já é uma "realidade presente" (Dodd), Cullmann mostrou, a propósito do Evangelho segundo Mateus, que o Reino de Deus "já" está presente com a vinda de Jesus (Cf. Mt 4,17; 5,3.10; 11,3ss.12; 12,28), mas "ainda não" se realizou plenamente (Cf. Mt 7,21; 8,11; $13,43 ; 16,28 ; 25,34)$ e que os cristãos vivem entre esse "já" e esse "ainda não" do reinado de Deus; "vivem já sob o reinado de Cristo, mas esperam ainda seu reinado glorioso". As parábolas do capítulo 13, particularmente a parábola sobre "o joio e o trigo" (Mt 13,24-30.36-43), diz ele, mostram claramente essa 
dupla realidade do reinado de Deus: "A semente já foi lançada, mas nós ainda não estamos no tempo da colheita" (CULMANN, 1968, p. 38s). Desde então, tornou-se comum falar de uma tensão escatológica entre o "já" e o "ainda não" do reinado de Deus, para além de todo historicismo e de todo espiritualismo. E isso foi decisivo para a recuperação da dimensão histórica do reinado de Deus.

Vinculado a este aspecto bíblico-teológico da tensão escatológica do reinado de Deus está o esforço de superação do dualismo "natural $X$ sobrenatural" na teologia contemporânea. Não podemos entrar aqui na história longa e complexa desse tema (Cf. LADÁRIA, 2003, p. 313-343), apenas destacar que, o que a princípio seria uma forma, mesmo que ambígua, de afirmar e salvaguardar a gratuidade do dom salvífico de Deus acabou produzindo um dualismo que "traz consigo o perigo de fazer de Deus e da vocação sobrenatural algo extrínseco ao ser humano, alguma coisa de que se pode abstrair e que não é necessária para ser homem" (LADÁRIA, 2003, p. 339). No esforço de superação desse dualismo, Henri de Lubac (desejo natural de ver a Deus) e Karl Rahner (existencial sobrenatural), não obstante ambiguidades e hesitações, abriram caminho para a superação de sua variante histórica: história sagrada X história profana. É verdade que Rahner continua falando de duas histórias, mesmo que se trate de histórias "coextensivas" (RAHNER, 1989, p. 176). Mas abriu caminho para a superação do dualismo "história da salvação X história universal" e para afirmação da unidade da história, uma das teses mais importantes e mais decisivas no processo de recuperação da historicidade do reinado de Deus e de renovação da teologia.

Tudo isso deságua no Concílio Vaticano II, particularmente em sua compreensão da Igreja como "sacramento" ou "sinal e instrumento" de salvação ou do reinado de Deus no mundo (Cf. $L G, 1,9,48$; GS 42, 45; AG, 1,5) e em sua incipiente teologia dos "sinais dos tempos" (CF. GS, 4, 11, 45; UR, 4). A Constituição Pastoral Gaudium et Spes, sobre a Igreja no mundo de hoje, destaca e desenvolve de modo particular a referência constitutiva e fundamental da Igreja ao mundo: Ela é e deve ser sempre mais sacramento de salvação ou do reinado de Deus no mundo: "A comunidade cristã se sente verdadeiramente solidária com o gênero humano e com sua história" (GS, 1). E de tal modo que "as alegrias e as esperanças, as tristezas e as angústias dos 
homens de hoje, sobretudo dos pobres e de todos os que sofrem, são também as alegrias e as esperanças, as tristezas e as angústias dos discípulos de Cristo. Não se encontra nada verdadeiramente humano que não thes ressoe no coração" (GS, 1). Por essa razão, o Concílio deseja estabelecer um "diálogo" do "povo de Deus congregado por Cristo" com "toda a família humana, à qual esse povo pertence" sobre os "vários problemas" que afetam a humanidade nos dias atuais, "iluminando-os [com] a luz tirada do Evangelho e fornecendo ao gênero humano os recursos de salvação que a própria Igreja, conduzida pelo Espírito Santo, recebe de seu fundador". Com isto, a Igreja não pretende senão "continuar a obra do próprio Cristo que veio ao mundo para dar testemunho da verdade, para salvar e não para condenar, para servir e não para ser servido" (GS, 3).

Vale a pena ler com atenção aqui uma afirmação da Gaudium et Spes que, não raras vezes, é utilizada para distorcer seu sentido fundamental:

A missão própria que Cristo confiou à sua Igreja por certo não é de ordem política, econômica ou social. Pois a finalidade que Cristo lhe prefixou é de ordem religiosa. Mas, na verdade, desta mesma missão decorrem funções ${ }^{3}$, luzes e forças que podem auxiliar a organização e o fortalecimento da comunidade humana segundo a lei de Deus $(G S, 42)$.

\section{A propósito desse texto, afirma Ignacio Ellacuría:}

É preciso esclarecer, aqui, o que significa que a missão não é de ordem política, econômica ou social, esclarecimento exigido pelo próprio texto que fala de como a missão religiosa reverte sobre o político, o econômico e o social. Efetivamente, a Igreja tem uma missão própria que não se identifica com a missão do Estado, nem com a dos partidos políticos, nem com a das empresas, nem com a dos sindicatos, nem com a das próprias organizações populares. Distingue-se de todas essas instituições pelo fim que a Igreja pretende e pelos meios que lhes são próprios, mas não se distingue por se referir ao que não fosse próprio das outras instituições. Nada do humano é estranho ao cristianismo; o próprio do cristianismo é o fim que se persegue com o humano e os meios com os quais se busca a realização desse fim. Daí que a missão da Igreja tenha a ver com o político, com o econômico e com o social. Não é dessa ordem, mas tem a ver com cada uma dessas ordens. O Concílio formula esse ter a ver em termos de ter funções, luzes e energias para que a sociedade humana seja como Deus quer. Portanto, a Igreja tem que introduzir no político, no econômico e no social não apenas luzes e energias, mas também funções que deem mais realidade a essas luzes e energias (ELLACURÍA, 1993, p. 693).

\footnotetext{
${ }^{3}$ A versão portuguesa da Editora Vozes curiosamente traduz "múnus" por "benefícios". A versão portuguesa do site do Vaticano traduz por "encargo" e a versão espanhola usada por Ellacuría no texto que aparece no parágrafo seguinte traduz por "funções".
} 
A razão última dessa abertura e desse serviço da Igreja ao mundo tem a ver com sua missão de ser "sinal e instrumento" de salvação ou do reinado de Deus no mundo. Enquanto presente no mundo e a serviço da salvação do mundo, a Igreja está constitutivamente referida ao mundo. Ela não pode se pensar e se configurar independentemente do mundo nem muito menos em oposição a ele. Enquanto lugar e destinatário da missão da Igreja, o mundo é um momento do processo mesmo em que essa missão salvífica se realiza. Não há lugar aqui para oposição entre Igreja e mundo (Cf. GS, 43). A preocupação e o envolvimento com os problemas do mundo aparecem como algo constitutivo da missão da Igreja (Cf. GS, 11, 42, 89). O Documento chega a afirmar que o "divórcio entre a fé professada e a vida cotidiana de muitos deve ser enumerado entre os erros mais graves do nosso tempo" e que "ao negligenciar os seus deveres temporais, o cristão negligencia os seus deveres para com o próximo e o próprio Deus e coloca em perigo a sua salvação eterna" (GS, 43).

Esse será o ponto central e determinante do processo de recepção do Concílio na América Latina a partir da Conferência de Medellín e da teologia da libertação. De fato, a grande novidade de Medellín foi abordar a eclesiologia conciliar "a partir da Gaudium et Spes e da teologia dos sinais dos tempos que constituem a originalidade maior do Vaticano II e do que João XXIII desejava do Concílio" (CODINA, 2017, p. 303). Isso já aparece claramente no tema da Conferência: "Presença da Igreja na atual transformação da América Latina". Aparece de maneira inequívoca na Introdução do Documento Final: começa afirmando que "a Igreja latino-americana, reunida na II Conferência Geral de seu Episcopado, situou no centro de sua atenção o homem deste continente que vive um momento decisivo de seu processo histórico" e, com isso, “não se acha 'desviada', mas 'voltou-se' para o homem, consciente de [que] 'para conhecer Deus é necessário conhecer o homem"”; fala do "momento histórico" vivido na América Latina (anseio de emancipação e de libertação) e o interpreta como um "evidente signo do Espírito"; e termina reafirmando que toda "reflexão [da conferência] orientou-se para a busca de forma de presença mais intensa e renovada da Igreja na atual transformação da América Latina à 
luz do Concílio Vaticano II". Isso pode ser comprovado no conjunto do Documento Final (Cf. CELAM, 1987).

Particularmente relevante na Introdução do Documento de Medellín é a afirmação de que

\begin{abstract}
assim, como outrora Israel, o antigo povo, sentia a presença salvífica de Deus quando ele o libertava da opressão do Egito, quando o fazia atravessar o mar e o conduzia à conquista da terra prometida, assim também nós, novo povo de Deus, não podemos deixar de sentir seu passo que salva quando se dá o "verdadeiro desenvolvimento" que é, para cada um e para todos, a passagem de condições de vida menos humanas para condições de vida mais humanas (CELAM, 1987, p. 7).
\end{abstract}

A importância fundamental e decisiva dessa afirmação reside no fato de não apenas se referir e reafirmar a historicidade da salvação ou de reinado de Deus, mas em indicar o como de sua realização histórica. A salvação não apenas se realiza na história ou tem uma dimensão histórica, mas realiza-se em termos de libertação de toda forma de injustiça, opressão e sofrimento. Essa é a originalidade e a insuperabilidade de Medellín: Tratar a salvação em termos de libertação. Aqui estão a origem e o princípio da evangelização libertadora e da teologia da libertação desencadeadas pela conferência de Medellín no continente latino-americano, com repercussões no conjunto da Igreja, inclusive no magistério romano que, aos poucos, vai assumindo a libertação ou a opção pelos pobres como aspecto fundamental da revelação, da fé e teologia cristãs.

Este é sem dúvida nenhuma o ponto fulcral ou o cerne da teologia da libertação em suas mais diversas configurações e expressões: salvação como libertação. Todas as teologias da libertação são teologias da salvação ou do reinado de Deus que se historiciza em termos de libertação das mais diferentes formas de opressão, injustiça e sofrimento. Não apenas tratam da historicidade ou da dimensão histórica da salvação ou do reinado de Deus, mas tratam dessa historicidade em termos de libertação. A teologia da libertação, diz Gustavo Gutiérrez, não é apenas (mais) uma teologia da "práxis", mas uma teologia feita na "perspectiva do pobre". E isso é fundamental: "Se a teologia é uma reflexão a partir da práxis e sobre ela, então é importante ter presente que se trata da práxis de libertação dos oprimidos deste mundo" (GUTIÉRREZ, 1981, p. 294). Já no famoso livro Teologia da libertação: Perspectivas, Gutiérrez dedica um capítulo inteiro, o mais importante e decisivo do ponto de vista 
teológico, à problemática da relação entre "libertação e salvação" (Cf. GUTIÉRREZ, 2000, p. 199-239). Ignacio Ellacuría, de modo particular, enfrentou-se com essa problemática, fazendo dela o cerne de sua teologia (Cf. AQUINO JÚNIOR, 2010, p. 161-169).

Importa, aqui, insistir no fato que a redescoberta e a retomada da historicidade ou da dimensão histórica da salvação ou reinado de Deus constituem a novidade mais importante e mais controvertida do processo de renovação teológica do século XX que culmina no Concílio Vaticano II e que será assumida e formulada na América Latina em termos de libertação e/ou opção preferencial pelos pobres.

\section{Critério de realização e verificação históricas do reinado de Deus}

Falar da salvação ou do reinado de Deus em termos de libertação ou a partir e na perspectiva dos pobres e marginalizados nada tem a ver com instrumentalização político-ideológica da fé e da teologia, como é comum ouvir dos críticos e opositores das teologias da libertação - comumente e ironicamente vinculados aos grupos dominantes da sociedade e em defesa de seus interesses (combate a opção pelos pobres a partir da opção pelos ricos) e, nos últimos tempos, explícita e publicamente vinculados aos grupos políticos de extrema direita...

Mesmo a Instrução sobre alguns aspectos da "teologia da libertação", da Congregação para a Doutrina da Fé, presidida pelo então cardeal Ratzinger, reconhecia que "o Evangelho de Jesus Cristo é mensagem de liberdade e força de libertação", que essa é uma "verdade essencial" da fé e que "a aspiração pela libertação, como o próprio termo indica, refere-se a um tema fundamental do Antigo e do Novo Testamento" (CONGREGAÇÃO PARA A DOUTRINA DA FÉ, 1984, p. 1, 5). O papa Francisco, em sua Exortação Apostólica Evangelii Gaudium, chamou atenção para o fato de que, "para a Igreja, a opção pelos pobres é mais uma categoria teológica que cultural, sociológica, política ou filosófica” (EG, 198): “No coração de Deus, ocupam lugar preferencial os pobres" (EG, 197); "esta preferência divina tem consequências na vida de fé de todos os cristãos”; “inspirada por tal preferência, a lgreja fez uma opção pelos 
pobres, entendida como uma 'forma especial de primado da prática da caridade cristã, testemunhada por toda Igreja"' $(E G, 198)$. Na mensagem que escreveu para o III Dia Mundial dos Pobres, o papa recorda que a "descrição da ação de Deus em favor dos pobres" constitui um "refrão permanente da Sagrada Escritura" (FRANCISCO, 2019).

De fato, se tem algo que não se pode negar nem ofuscar na Sagrada Escritura é a centralidade dos pobres e marginalizados na história da salvação. Deus aparece (revelação) como Go'el que resgata seus parentes da escravidão, como Rei que faz justiça aos pobres e oprimidos, como Pastor que apascenta suas ovelhas e as protege dos lobos, como Pai que cuida de seus filhos e os socorre em suas necessidades. A relação com ele (fé) passa sempre pela observância e defesa do direito dos pobres e marginalizados, pela proximidade aos caídos à beira do caminho. Todas as imagens ou metáforas que a Escritura usa para falar da inter-ação entre Deus e seu povo (Go'el, Rei, Pastor, Pai, etc.) revelam a centralidade dos pobres e marginalizados, de modo que a salvação deles constitui o coração da história de Deus com seu povo.

$E$, aqui, a imagem/metáfora do reinado de Deus é particularmente relevante. Por se tratar de uma imagem/metáfora proveniente do mundo político, centrada na justiça aos pobres e marginalizados, destaca melhor a dimensão social da ação salvífica de Deus (contra tendências individualistas) e oferece um critério de realização e verificação históricas (contra tendências idealistas ou espiritualistas).

Joachim Jeremias, exegeta alemão, afirma que reinado de Deus, "tema central da proclamação pública de Jesus" (JEREMIAS, 2008, p. 160), é um "conceito dinâmico" que indica a "soberania real de Deus em ação" e que "sua marca principal é que Deus está realizando o ideal da justiça real, sempre ansiado, mas nunca cumprido na terra". Mas adverte que, para os povos do oriente, concretamente para Israel, "a justiça real não consistia primordialmente numa aplicação imparcial do direito, mas na proteção que o rei estende aos desamparados, fracos e pobres, às viúvas e aos órfãos" (JEREMIAS, 2008, p. 162). Por essa razão, diz ele, "com a constatação de que Jesus anunciou a consumação do mundo como algo que estava a se irromper, ainda não se descreveu totalmente sua pregação da basileia; pelo contrário, seu traço decisivo ainda não foi nomeado". Ele consiste precisamente na 
"oferta de salvação feita por Jesus aos pobres". Aqui está o "coração da proclamação de Jesus" (JEREMIAS, 2008, p. 176).

Jacques Dupont, exegeta belga, na mesma direção, recorda que nos Evangelhos "os pobres são vistos como os beneficiários privilegiados do Reino de Deus" e que esse privilégio não deve ser procurado "por uma análise gratuita da psicologia dos próprios pobres, mas no conteúdo mesmo da boanova que lhe é anunciada" (DUPONT, 1976, p. 51). Adverte que a boa notícia do reinado de Deus só pode ser compreendida em referência ao "ideal régio" do Antigo Oriente Próximo, no qual "o rei, por sua própria missão, é o defensor daqueles que não são capazes de se defender por si mesmos" — "é o protetor do pobre, da viúva, do órfão e do oprimido" (DUPONT, 1976, p. 53). Neste sentido, diz ele, "poder-se-á compreender perfeitamente que o anúncio do advento do Reino de Deus constitui uma boa-nova, precisamente para os pobres e para os desgraçados" (DUPONT, 1976, p. 54).

Giuseppe Barbaglio, exegeta italiano, recorda que "o símbolo régio era expressivo de uma imagem da divindade protetora dos fracos e dos oprimidos, isto é, dos pobres, tomando o partido deles para fazer justiça" — "uma justiça superior, 'partidária', a favor dos pobres e contra a violência dos prepotentes e dos opressores". Afirma que "Jesus vive tal imagem de Deus dentro de si e a manifesta com clareza na primeira bem-aventurança" (BARBAGLIO, 2011, p. 292). Adverte que "os pobres são beneficiários do poder régio de Deus não por eventuais méritos próprios, morais ou religiosos", mas porque o próprio Deus é o "defensor dos que defesa não conseguem ter" e o " "vingador' [...] da boa e justa causa deles". E conclui afirmando que Jesus não espera um "domínio intemporal de Deus", mas um "domínio soberano que influi sobre o hoje histórico", "um futuro do qual um fragmento entra a qualificar o presente" (BARBAGLIO, 2011, p. 294).

Importa destacar, aqui, com esses autores, duas coisas: 1) O reinado de Deus, anunciado por Jesus, não é uma realidade puramente espiritual, atemporal e ultraterrena, mas uma realidade que "já" está presente na história, embora "ainda não" tenha se realizado plenamente; é uma realidade presente e futura ao mesmo tempo; 2) Tampouco é uma realidade abstrata, socialmente neutra ou indiferente, mas uma realidade que transforma a sociedade a partir de suas vítimas. Sua característica fundamental é a "oferta de salvação aos 
pobres", daí seu caráter de parcialidade pelos pobres e marginalizados. Deus reina fazendo justiça aos pobres, isto é, assumindo sua causa...

Isso é fundamental para a problemática da historicidade do reinado de Deus. Além de afirmar sua dimensão histórica (realidade "já" presente e operante na história), oferece um critério de realização e verificação históricas (justiça aos pobres e marginalizados). Certamente, o reinado de Deus não se esgota na justiça aos pobres. Diz respeito à vivência do mandamento do amor fraterno (Cf. Jo 13,34; 15,12) que se estende inclusive aos inimigos (Cf. Mt 5,4s), do perdão (Cf. Mt 18,215), da humildade (Cf. LC 14,7-11; 18,9-14), do serviço (Cf. Jo 13,11-17) etc. Mas tem na justiça ou no serviço aos pobres e marginalizados da sociedade sua medida e seu critério escatológicos por excelência (Cf. LC 10,25-37; Mt 25,31-46). Aqui se pode compreender a afirmação de Sobrino de que "fora dos pobres não há salvação" (Cf. SOBRINO, 2007) ou a insistência do papa Francisco de que os pobres são o "protocolo com base no qual seremos julgados" (FRANCISCO, 2016) ou o "passaporte para o paraíso" (FRANCISCO, 2017).

\section{Considerações finais}

A problemática do reinado de Deus é central e decisiva na vida e missão de Jesus e de sua Igreja. E é muito mais ampla e complexa do que pode parecer à primeira vista e não deve ser reduzida a nenhum de seus aspectos ou de suas dimensões. Ela pode ser abordada do ponto de vista bíblico, históricosistemático ou pastoral e pode desenvolver mais sua dimensão pessoal, comunitária ou socioambiental.

Embora pressupondo e se apoiando nos estudos bíblicos (abordagem bíblica) e tendo em vista sua relevância atual e a ação pastoral-evangelizadora da Igreja (abordagem pastoral), nossa abordagem quis destacar como a dimensão histórica do reinado de Deus foi se perdendo e como foi redescoberta na teologia contemporânea, particularmente na teologia latinoamericana (abordagem histórico-sistemática).

O Concílio Vaticano II e a Conferência de Medellín são marcos fundamentais nesse processo de redescoberta da historicidade da salvação ou do reinado de Deus. Ao compreender a Igreja como "sacramento" ou "sinal e instrumento" de salvação ou do reinado de Deus no mundo, o Concílio se 
enfrenta com a tarefa e o desafio de discernimento dos "sinais dos tempos", abrindo espaço para o reconhecimento da dimensão histórica da salvação ou da densidade salvífica dos acontecimentos históricos - tarefa apenas intuída e indicada... A Conferência de Medellín, por sua vez, concretiza essa historicidade da salvação ou do reinado de Deus em termos de libertação de todas as formas de injustiça, opressão e marginalização ou de "opção pelos pobres", levando a uma inserção da Igreja nos processos de transformação da sociedade a partir e em vista dos direitos dos pobres e marginalizados. E isso, muitas vezes, até as últimas consequências como comprova o martírio de tantos cristãos por causa dos pobres...

O Papa Francisco tem retomado e reafirmado com vigor e criatividade esse dinamismo teológico-pastoral desencadeado pelo Concílio e sua recepção latino-americana, formulado por ele em termos de "Igreja pobre e para os pobres" ou de "Igreja em saída para as periferias do mundo". Aqui residem a força e o impacto evangélicos de seu ministério pastoral e da reforma eclesial por ele desencadeada: Renovar toda a Igreja no Evangelho, o que significa renovar toda a Igreja a partir do compromisso com os pobres, tornando-a cada vez mais "sinal e instrumento" do reinado de Deus nesse mundo (CF. AQUINO JÚNIOR, 2019). Os pobres e marginalizados são, n’Ele, juízes e senhores de nossas vidas e da vida de nossas comunidades e, assim, critério determinante de nossa participação (vinde benditos...) ou exclusão (afastai-vos malditos...) do banquete escatológico do reinado de Deus (Cf. Mt 25,31-46).

\section{Referências}

AQUINO JÚNIOR, F. A teologia como intelecção do reinado de Deus: O método da teologia da libertação segundo Ignacio Ellacuría. São Paulo: Loyola, 2010.

AQUINO JÚNIOR, F. Renovar toda a Igreja no Evangelho: Desafios e perspectivas para a conversão pastoral da Igreja. Aparecida: Santuário, 2019.

BARBAGLIO, G. Jesus, hebreu da Galileia: Pesquisa histórica. São Paulo: Paulinas, 2011. CELAM. Conclusões de Medellín. São Paulo: Paulinas, 1987.

COMBLIN, J. A profecia na Igreja. São Paulo: Paulus, 2008.

COMPÊNDIO DO VATICANO II: Constituições, decretos, declarações. Petrópolis: Vozes, 1995. 
CONGREGAÇÃO PARA A DOUTRINA DA FÉ. Instrução sobre alguns aspectos da “Teologia da Libertação”. São Paulo: Loyola, 1984.

CODINA, V. Hacer teología en medio de los pobres. Revista Latinoamericana de Teología, v. 102, p. 301-309, 2017.

CULMANN, O. Einführung in das Neue Testament. München und Hamburg: Siebernstern Tachenbuch, 1968.

DUPONT, J. Os pobres e a pobreza segundo os ensinamentos do Evangelho e dos Atos dos Apóstolos. In: DUPONT, J. et al. A pobreza evangélica. São Paulo: Paulinas, 1976. p. 37-66.

ELLACURÍA, I. Comentarios a la Carta Pastoral. In: Escritos Políticos II. San Salvador: UCA, 1993. p. 679-732.

ELLACURÍA, I. Historia de la salvación. In: Escritos teológicos I. San Salvador: UCA, 2000. p. 597-628.

FABRIS, R. Jesus de Nazaré: História e interpretação. São Paulo: Loyola, 1988.

FRANCISCO. Exortação Apostólica Evangelii Gaudium: Sobre o anúncio do Evangelho no mundo atual. São Paulo: Paulinas, 2013.

FRANCISCO. Via-sacra com os jovens na XXXI Jornada Mundial da Juventude na Polônia 29 jul. 2016. Disponível em: http://w2.vatican.va/content/francesco/pt/speeches/2016/july/documents/papafrancesco_20160729_polonia-via-crucis.html

FRANCISCO. Homilia no I Dia Mundial dos Pobres. 19 nov. 2017. Disponível em: https://w2.vatican.va/content/francesco/pt/homilies/2017/documents/papafrancesco_20171119_omelia-giornata-mondiale-poveri.html

FRANCISCO. Mensagem para o III Dia Mundial dos Pobres. 2019. Disponível em: http://w2.vatican.va/content/francesco/pt/messages/poveri/documents/papa-

francesco_20190613_messaggio-iii-giornatamondiale-poveri-2019.html

GIMÉNEZ, J. Lo Último desde los últimos: Esbozo de esperanza y escatología cristianas. Maliaño: Sal Terrae, 2018.

GONZÁLEZ, A. El problema de la historia en teología de Gustavo Gutiérrez. Revista Latinoamericana de Teología, v. 18, p. 335-364, 1989.

GONZÁLEZ, A. La historia como revelación de Dios según Pannenberg: Reflexión crítica. Revista Latinoamericana de Teología, v. 25, p. 59-81, 1992.

GONZÁLEZ, A. Reinado de Dios e imperio: Ensayo de teología social. Santander: Sal Terrae, 2003.

GUTIÉRREZ, G. A força histórica dos pobres. Petrópolis: Vozes, 1981. 
GUTIÉRREZ, G. Teologia da libertação: Perspectivas. São Paulo: Loyola, 2000.

JEREMIAS, J. Teologia do Novo Testamento. São Paulo: Hagnos, 2008.

LADÁRIA, L. "Natural e sobrenatural”. In: SESBOÜÉ, Bernard (Dir.). História dos Dogmas 2: O homem e sua salvação. São Paulo: Loyola, 2003. p. 313-343.

LÉON-DUFOUR, X. Agir segundo o Evangelho: Palavra de Deus. Petrópolis: Vozes, 2003. PETERSON, E. El monoteísmo como problema político. Madrid: Trotta, 1999.

RAHNER, K. Curso Fundamental da Fé. São Paulo: Paulus, 1989.

SCHNACKENBURG, R. Reino y reinado de Dios: Estudio bíblico-teologico. Madrid: Ediciones Fax, 1974.

SOBRINO, J. Jesus, o Libertador: A história de Jesus de Nazaré. Petrópolis: Vozes, 1996.

SOBRINO, J. Fuera de los pobres no hay salvación: Pequeños ensayos utópicoproféticos. Madrid: Trotta, 2007.

VELASCO, R. A Igreja de Jesus: Processo histórico da consciência eclesial. Petrópolis: Vozes, 1996. 